\title{
Increasing Energy Prices as a Stimulus for Entrepreneurship in Renewable Energies: Ownership Structure, Company Size and Energy Policy in Companies in Poland
}

\author{
Piotr Żuk ${ }^{1, *(1)}$ and Paweł Żuk ${ }^{2}$ \\ 1 The Centre for Civil Rights and Democracy Research, 51-003 Wroclaw, Poland \\ 2 Department of Sociology and Social Policy, Wroclaw University of Economics, 53-345 Wroclaw, Poland; \\ pawel.zuk@ue.wroc.pl \\ * Correspondence: piotr.zuk@protonmail.com
}

check for updates

Citation: Żuk, P.; Żuk, P. Increasing Energy Prices as a Stimulus for Entrepreneurship in Renewable Energies: Ownership Structure, Company Size and Energy Policy in Companies in Poland. Energies 2021, 14, 5885. https://doi.org/10.3390/ en14185885

Academic Editor:

Dimitrios Katsaprakakis

Received: 14 July 2021

Accepted: 15 September 2021

Published: 17 September 2021

Publisher's Note: MDPI stays neutral with regard to jurisdictional claims in published maps and institutional affiliations.

Copyright: (c) 2021 by the authors. Licensee MDPI, Basel, Switzerland. This article is an open access article distributed under the terms and conditions of the Creative Commons Attribution (CC BY) license (https:// creativecommons.org/licenses/by/ $4.0 /)$.

\begin{abstract}
Can rising electricity prices be a driving force for energy transition in countries where the energy sector is d pendent on coal? The goals of the article are to determine the readiness of entrepreneurs to invest in renewable energy and indicate the variables (company size, the length of time it has operated in the market, the form of ownership and the sector of the economy represented) that influence companies' greater interest in making savings in energy costs. The research sample in the survey carried out using the computer-assisted telephone interviewing (CATI) method included representatives of entrepreneurs from all regions of Poland. The result for all respondents was checked with the z-test (proportion test). The results obtained on a sample of 400 Polish entrepreneurs responsible for development policies in their companies explain which variables have the greatest impact on the decisions of companies in the context of investments in renewable energy: in Poland, greater interest in renewable energy can be observed in the public sector and in larger companies. The conclusion that can be drawn from this research is that the ownership structure of a company plays an important role in looking for savings by investing in renewable energy.
\end{abstract}

Keywords: entrepreneurs; energy prices; energy saving; European Green Deal (EGD); ownership structure; renewable energies

\section{Introduction}

Since April 2020, wholesale energy prices in Poland have been the highest in the European Union (EU). The Polish government's attachment to coal, increasingly obsolete coal-fired power plants and the lack of a clear energy policy will lead to increased dependence on energy imports and price increases for end users [1]. Due to these trends, citizens start to invest in renewable energy to avoid high electricity bills. The years 2019 and 2020 were a period of rapid development of photovoltaics - the main driving force was prosumer micro-installations. The photovoltaic market was the fastest growing of all renewable energy sectors in Poland. The total installed capacity in photovoltaic sources was almost 1500 MW by the end of 2019, exceeding 1950 MW in May 2020. Most of this capacity was produced by photovoltaic micro-installations with a capacity of up to $50 \mathrm{~kW}$ each, which were installed by prosumers (individuals and small entrepreneurs), not by the state or big business [2].

At the same time, since January 2021, there has been an additional charge on electricity bills in Poland called the 'capacity fee'. The capacity fee is officially a fee for the readiness to secure the supply of electricity and is intended to ensure energy security (constant electricity supply). In practice, this is a hidden surcharge to cover the growing costs of maintaining the power plants which cannot survive by selling energy. This mainly applies to old coal-fired power plants. Although the fee applies to all energy consumers, its introduction has mainly hit companies and entrepreneurs. The government has added PLN 
76.20 (approx. USD 20) for each $1 \mathrm{MWh}$ taken from the grid on working days from 7:00 a.m. to 9:00 p.m., which has translated into an increase in electricity prices of approximately $16 \%$. The larger the company and the greater the consumption of electricity, the higher the charges. It is estimated that, in the case of factories and mines, the additional annual fees may increase by approximately PLN 8 million (approx. USD 2.1 million). In the case of smaller workplaces, this cost is estimated at approximately PLN 120,000 (approximately USD 31,500) per year. With regard to small businesses, the costs related to the capacity fee may amount to approximately PLN 13,000 (approximately USD 3400) per year [3]. Moreover, due to the dependence of the energy sector in Poland on coal, a constant upward trend in energy prices can be expected in this country in the coming years.

Will these energy price trends affect the attitudes of entrepreneurs towards investing in renewable energy sources? The article describes the results of quantitative research carried out using the computer-assisted telephone interviewing (CATI) method on a sample of 400 Polish entrepreneurs representing various sectors of the economy.

The aim of this article is to show the relations between the attitudes of entrepreneurs in Poland towards investing in renewable energy as a way to avoid rising energy fees. Based on the research results, attempts were made to specify the variables (company size, the length of time it has operated in the market, the form of ownership and the type of economic sector) that influence companies' greater interest in savings in energy costs. At the same time, the article tries to emphasise the importance of strategies taken by entrepreneurs to effectively implement the European Green Deal (EGD). Entrepreneurs in Poland now have several options to counteract the effects of rising energy prices. The most optimal solution is self-consumption of renewable energy generated on a company's premises, combined with the sale of unused energy, for example, in the net settlement formula (it is only possible for sources of up to $50 \mathrm{~kW}$ ), sale at the statutory price from the previous quarter, a commercial agreement with a trading company or in the form of power purchase agreements (PPA) [4]. In practice, the best solution for an enterprise that consumes large amounts of energy is to become a business prosumer and invest in its own photovoltaic power plant, ensuring full or partial satisfaction of the company's energy needs. However, according to data from the Institute for Renewable Energy (IRE), at the end of 2020, there were only about 65 large business prosumers in Poland, generating energy from large roof sources or solar farms. Additionally, around $450 \mathrm{MW}$ of photovoltaic micro-installations were in operation, supplying energy to micro and small companies [4]. What factors make entrepreneurs think more favourably about investing in renewable energy? Is it possible to identify any permanent social mechanisms that explain this issue?

This article contributes to the discussion by emphasising the importance of structural variables regarding the types of businesses run by entrepreneurs and their relationship to involvement in renewable energy investments. It is necessary to add to the social dimension some hard and objective data from the economic sphere: the company size, the length of time it has operated in the market, the type of economic sector, as well as the form of ownership related to the management model, organisational culture and decision-making. In the countries of Eastern Europe, which underwent a systemic transformation and a rapid change in economic relations in the 1990s, the type of company ownership and its size could have significantly influenced the implemented model of employee policy and the attitude towards trade unions, among other things [5]. Do the same elements related to the structural differentiation of companies affect attitudes towards investing in renewable energy? Checking this was one of the goals of the conducted research.

Section 2 describes the context of energy policy in Poland-its entanglement in coal, the main goals of the state's energy policy, the challenges of rising energy prices and the importance of the Eastern European region for the implementation of the EGD. In Section 3, the literature is reviewed to discuss the factors that influence entrepreneurs' decisions in the context of investing in renewable energy. Section 4 outlines the research methods and describes the research sample. Section 5 presents the research results-expected increases in 
energy prices, measures taken in companies to save energy, readiness to invest in renewable energy by the type of company and form of ownership.

\section{Energy Prices in Poland and the Socio-Energy Context}

The record level of wholesale energy prices in Poland is directly related to the dependence of the energy sector on coal. Considering the costs of servicing gas- and coal-fired power plants (taking the prices of EU Emissions Trading System [ETS] allowances into account), it can be seen that, since April 2019, it has been cheaper to generate electricity from gas than from hard coal. On the one hand, this trend is shaped by lower gas prices and, on the other hand, the rising costs of coal-based energy are related to the increase in the prices of EU ETS allowances [1]. Many countries have an energy reserve in gas-fired power plants. In Poland, however, there are no such reserves (only $4.8 \%$ of energy was produced from gas in 2020) [6]. As a result, wholesale electricity prices in Poland remain indifferent to the falls in gas prices and have become the highest in EU countries since April 2020 (Figure 1).

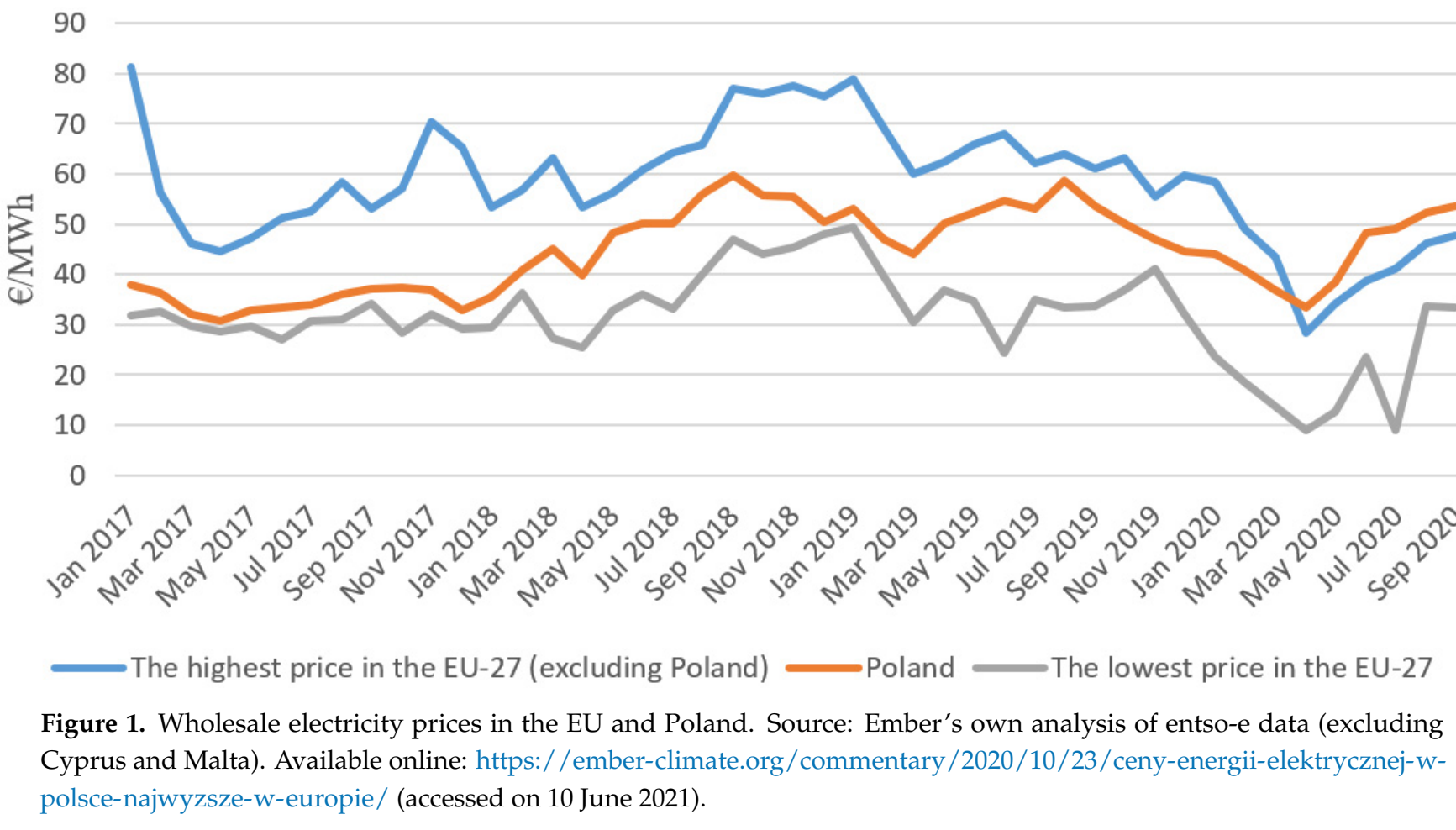

Poland remains the largest European economy based on coal, and hard coal is the main source of energy although its total share of the energy mix is decreasing. In 2020, hard coal and lignite accounted for nearly $68 \%$ of the energy produced (Figure 2) [6]. Compared to other European countries, the Polish energy system is the most dependent on fossil fuels and has one of the smallest shares of renewable energy in the overall energy balance (next to the Czech Republic and Hungary) (Figure 3) If there is no radical shift in climate and energy policy in Poland, the EU environmental policy and orientation towards the European Green Deal (EGD) may further alienate Poland in the area of economic and environmental policy [7]. This may also lead to further increases in electricity prices, which also result from the fact that the coal mined in Poland is more expensive than imported coal [8]. Poland's attachment to coal energy has many reasons. First, it is the legacy of the communist period, when coal was called 'black gold' and a 'national treasure' [9]. In the 1950s and also in the following decades, coal was the main source of the inflow of foreign currencies to the Polish economy for which products from the West were purchased. Coal was also the basis for the reconstruction of industry and the electrification of the country after the devastation of World War II. Between 1950 and 1970, the total energy consumption 
in Poland increased from 600 to 10,000 gigawatt hours [10]. The special importance of coal at that time also resulted from its political and military functions-coal converted into coke was necessary for steel smelting. The expansion of ironworks was necessary for military purposes and constructing tanks for the Warsaw Pact countries during the Cold War [11].

Hard coal-fired power plants and heat and power plants 43.6

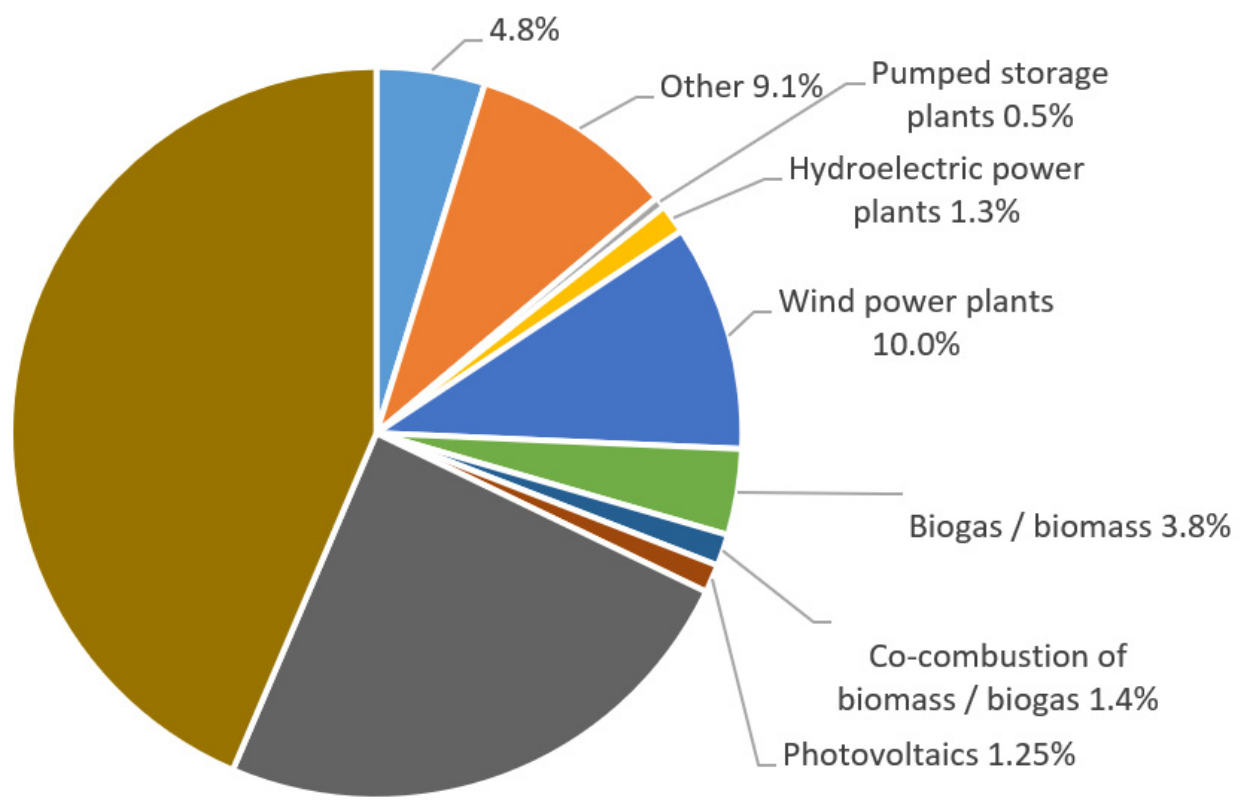

Lignite-fired power plants $24.3 \%$

Figure 2. Structure of electricity production (January-December 2020).

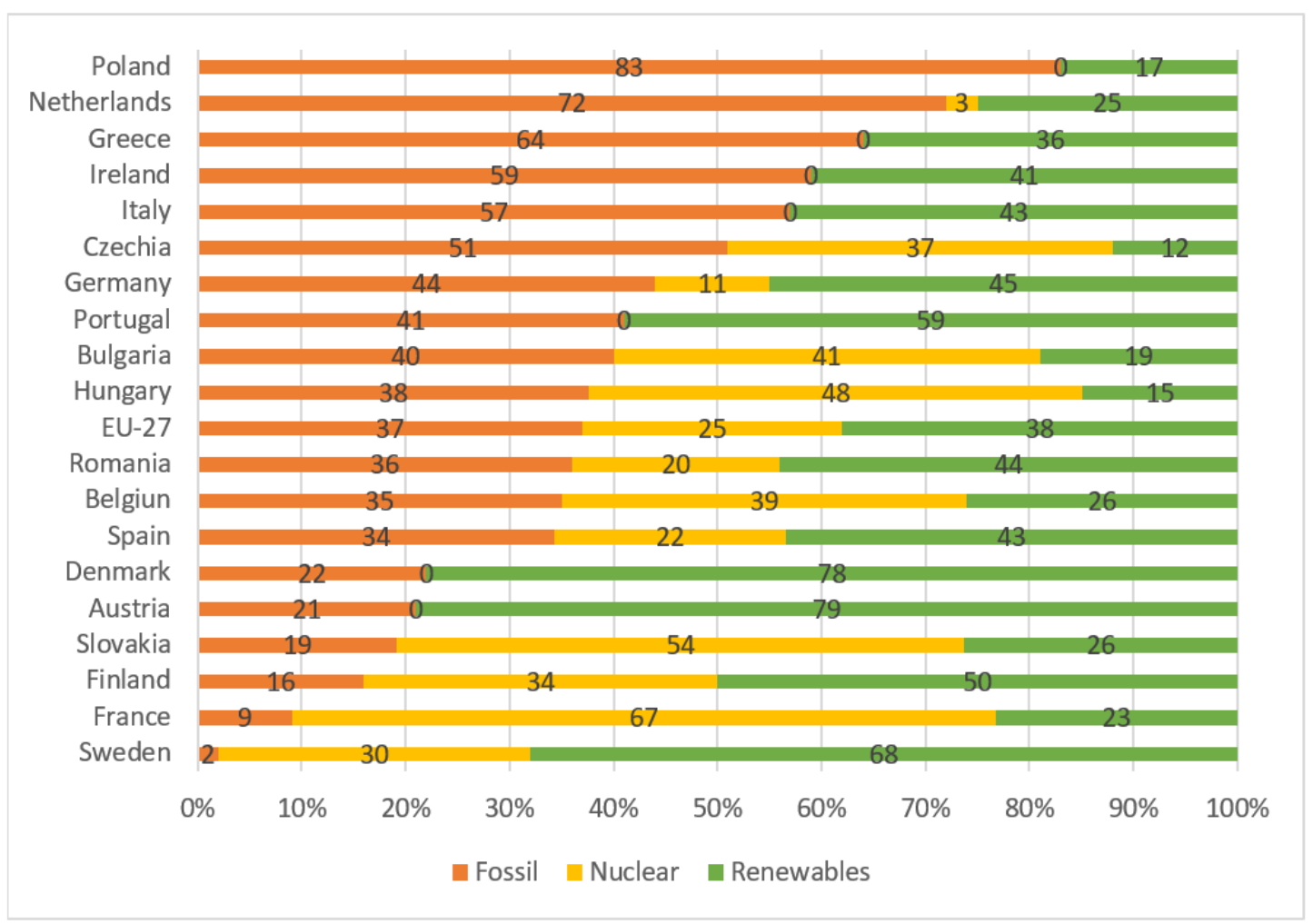

Figure 3. Fossil fuels vs. Renewables. Share of electricity generation. Source: Europe's Pover Sector in 2020, published by Ember and Agora Energiewende on 25 January 2021. 
Today, in turn, the abandonment of coal in the energy sector is treated by the rightwing populist government in Poland as an EU pressure and unnecessary interference in the country's internal economic and energy policy, and ecology itself as an ideology flowing from the West and threatening national culture [12]. This narrative is supported by the pro-government media [13]. In addition to building a nationalist atmosphere to defend the position of coal in the energy sector, the government has been using slogans about 'defending energy sovereignty' and 'ensuring energy security' in recent years [14]. In general, the wave of nationalism and right-wing populism, which has moved through the countries of Eastern Europe three decades after the collapse of the Eastern bloc [15], made the Visegrád Group countries (The Czech Republic, Hungary, Poland and Slovakia) the main political and geographical area blocking the common climate and energy policy in the EU [16].

An important political reason slowing down and blocking the process of energy transition in Poland was also the government's fear of the mining trade unions' reaction [8]. The fact is that Poland lacks just transition plans for employees and cost calculations involving the transformation of mining regions. Such estimates of the costs of employee retraining and relocation from coal regions and $100 \%$ compensation insurance were created, for example, in the United States [17]. Hence, opposition to limiting the production and consumption of coal creates an informal coalition of various entities: coal corporations, trade unions, the government and some local authorities. Their opposition focuses on the prospect of losing business, negative experiences related to structural changes, concerns about energy security and the fear of increasing unemployment in the regions [18]. Another reason for their resistance to the slogans of energy transition is the fear of rising energy prices as a result of achieving the objectives of the EGD. However, data from ten EU countries from 2008 to 2016 show that the increase in energy production from renewable sources lowers wholesale electricity prices [19]. In Poland, paradoxically, the fear of abandoning coal causes a further increase in energy prices. Due to higher coal and electricity prices in Poland, energy imports also grow. Namely, in the first three quarters of 2020, 8\% of electricity in the country was imported. Moreover, $80 \%$ of the electricity imported $(8.6$ out of 10.4 terawatt hours) came from Germany, where wind and solar power translates into hours of very cheap electricity [1].

However, even energy transition does not ensure the strengthening of local renewable energy in Poland. In the state's energy policy plans contained in the government's document entitled 'The Energy Policy of Poland until 2040' published in March 2021 [20], the abandonment of coal does not increase the role of distributed and decentralised renewable energy - energy transition in Poland is planned to be primarily based on nuclear energy and large offshore wind farms. The planned increase in solar energy is small, hydropower is to remain at a trace level, and onshore wind energy is to be reduced (Table 1). Under Polish conditions, the role of small hydropower plants, which may contribute to energy transition, is underestimated (although hydropower may also disrupt natural ecosystems) [21] —so is the development of onshore wind power that has been blocked by the Act of 20 May 2016 on investments in the field of wind farms, which caused tax consequences, although this was not its purpose [22]. In the case of small entrepreneurs, micro wind turbines [23] could be a means of becoming independent from the pressure of rising electricity prices.

Delayed and centralised energy transition in Poland will reduce the competitiveness of the Polish economy in the long run-the cheaper workforce will not offset rising energy prices. In turn, lowering the competitiveness of the economy will strengthen the process of economic emigration to Western European countries [24]. This may apply not only to manual workers, but also to specialists. 
Table 1. Net electricity production forecast [TWh].

\begin{tabular}{ccccc}
\hline & $\mathbf{2 0 2 5}$ & $\mathbf{2 0 3 0}$ & $\mathbf{2 0 3 5}$ & $\mathbf{2 0 4 0}$ \\
\hline biomass and biogas & 6.6 & 7.4 & 8 & 7.5 \\
hard coal & 35.9 & 26.9 & 21.8 & 18.2 \\
lignite & 50.6 & 41 & 18.1 & 4.6 \\
nuclear energy & 0 & 0 & 16.7 & 33.4 \\
natural gas & 45.1 & 52.6 & 67.5 & 67.6 \\
hydropower & 1.8 & 1.8 & 1.9 & 1.8 \\
onshore wind energy & 25.4 & 23.1 & 14.5 & 22.1 \\
offshore wind energy & 0 & 24 & 39.2 & 39.4 \\
solar energy & 4.6 & 4.4 & 4.3 & 9.6 \\
\hline total & 170.1 & 181.1 & 191.9 & 204.2 \\
\hline
\end{tabular}

Source: Ministry of Climate and Environment in cooperation with the Government's Plenipotentiary for Strategic Energy Infrastructure and the Transmission System Operator PSE S.A.

\section{Changes in Energy Prices and Their Impact on Entrepreneurs' Investments in Renewable Energy}

A company's innovativeness is and will remain a key element in maintaining a competitive advantage in the market environment [25]. Although competitiveness in the countries of semi-periphery capitalism has also been generated through cheap labour and the exploitation of cheap natural resources [26], this stage is slowly coming to an end, due also to the rising prices of the latter. The significant position of energy prices in the operating costs of companies-primarily in energy-intensive industries-allows us to assume that the very threat and risk of an increase in energy prices forces entrepreneurs to take innovative measures. However, the opposite assumption can also be made that a sharp increase in energy prices may result in seeking savings and reducing investment in innovative solutions and new technologies [27]. Such trends have been observed, for example, in India, where the energy price increase has caused a decline in the investment expenditure by firms as a result of either an adverse effect on demand for output or an increase in the cost of production [28]. The trend observed in India, which is dependent on oil imports, is clear: 'crude oil price, public investment and real interest rate have detrimental effects on the growth of domestic private investment, whereas financial sector development, economic growth and globalisation help to boost up private investment' [29]. Just as India's recipe has been to invest in renewable energy and to become independent from oil, Poland needs to invest in renewable energy as soon as possible and to end its dependence on coal to avoid electricity price increases.

Generally, it can be said that the increasing prices of fossil energy will limit the demand for it, thus contributing to the development of renewable energy sources [30]. Although enhancing in industrial electricity price increased the energy cost of enterprises, it could force the enterprises to carry out technological innovation, improve technical efficiency and ultimately improve green total factor productivity [31]. The pace of these changes obviously depends on technological progress and the falling costs of investing in renewable energy, but also on certain social aspects. In this context, from the psychological perspective, specific types of personality and leadership profiles among entrepreneurs are indicated that contribute to the implementation of energy transition in companies [32]. On the other hand, from the socio-cultural perspective, the preferred model of management culture, the level and profile of entrepreneurs' education, their knowledge of environmental hazards and their orientation towards environmental policy will be important for the energy policy implemented in a company [33]. The attitude of entrepreneurs towards investments in renewable energy may also be influenced by their ideological beliefs: supporters of economic nationalism and climate sceptics do not back the goals of energy transition [34].

\section{Methodology}

The survey was conducted in October 2020 using the CATI method. The surveyed population consisted of representatives of companies operating in Poland and with at 
least ten employees. The respondents were representatives of these companies, who knew about and were responsible for the activities and development plans related to investing in energy efficiency (managerial staff, owners or co-owners of smaller companies). There was one respondent for each company. The average research effectiveness was 0.25 interviews per hour of work of one interviewer. Each interview lasted $15 \mathrm{~min}$ on average.

The results described in this article only concern a certain part of the research carried out. We focus on questions and answers related to investing in renewable energy sources. Other parts of the research tool concerned climate scepticism among entrepreneurs, their attitudes towards closing mines in Poland and opinions about the EU climate policy.

The research sample was selected with proportional stratified sampling without replacement. For this purpose, the strata were distinguished according to the following parameters: company size ( 4 strata), industry (20 strata) and province (16 strata). Thanks to the sample constructed in this way, the following variables were used in the study: the company size, the length of time it has operated in the market, the type of economic sector and the form of ownership.

The sampling frame was the BISNODE database. This database is currently the most up-to-date sampling frame of business entities available on the Polish market. In particular, this applies to companies with ten or more employees. The frame ensures even territorial coverage of the country (individual provinces and city size categories). Individual records of the database contain company descriptions, taking account of their industry, size measured by employment and location. Thanks to the above features of the indicated frame, it was possible to correctly stratify the sample, and to unambiguously classify individual entities to individual strata.

The research sample consisted of 400 people. Approximately (assuming the application of simple random sampling), the maximum error of estimation for a sample of 400 people is $4.9 \%$ (for the $50 \%$ fraction). In practice, the error rate was lower due to the stratification used. This was assumed to be the error rate acceptable for the study. The results were calculated using the SPSS software.

In order to maintain the same distribution of features in the sample as in the entire population of entrepreneurs in Poland, random iterative method weighting was used, taking into account the territorial distribution, as well as the industry and the size of the surveyed population of entrepreneurs. The variables of the surveyed entrepreneurs that were taken account of when designing the sample included the industry they represented, the company size and the place of business.

The statistical significance of the differences between the percentages for individual groups of respondents and the result for all respondents was checked with the z-test (proportion test). The significance of differences was tested at the significance level of 0.95 . The percentages that are statistically significantly different from the result for all respondents are marked with + (significantly higher) and - (significantly lower) in the tables.

The obtained quantitative data showing the dominant trends in the attitudes of Polish entrepreneurs towards renewable energy require further studies, including those carried out using qualitative methods (such as in-depth interviews and focus group interviews). They will make it possible to deepen the understanding of the relationship between rising electricity prices, company development plans and entrepreneurs' decisions about using renewable energy.

\section{Readiness to Invest in Renewable Energy and Take Measures to Reduce Energy Costs}

The research conducted so far has focused mainly on the socio-demographic characteristics of individual respondents which may contribute to energy transition or energy-saving attitudes. In Poland, in this context, it has been pointed out that higher education, better material position and a higher position in the social structure are factors that correlate with greater interest in renewable energy sources [35]. Higher education among women and the related greater openness to new solutions and technologies make women in Poland an important segment of support for energy transition [36]. However, there are no data 
that would define which types of companies and which entrepreneurs have a more open attitude to investing in renewable energy sources and how the expected increases in energy prices affect their interest in becoming business prosumers.

\subsection{Electricity Price Level Evaluation and Entrepreneurs' Forecasts Regarding Energy Prices}

According to the analyses of IRE, Poland will not avoid an increase in energy prices, which, in line with the IEO forecast, will increase (without taking into account inflation) from PLN 293 (about USD 77) in 2019 to PLN 347 (about USD 91) in 2030 and will only start falling from 2036. The authors of the report emphasise that Poland can possibly reduce the growth rate of energy prices, not only through the increase in fuel and energy imports, but also through the diversification of energy sources and wider use of its own renewable energy resources [37]. The coming years will show if this will happen. Currently, entrepreneurs can expect further increases instead. As regards electricity prices and other regulations, the general problems faced by entrepreneurs in Poland are the unpredictability and pace of changes introduced to regulations and fees. Clear and constant rules of the game can be a great help in functioning in the market. In the context of electricity fees, unchanging regulations and the related permanent tax breaks would certainly be incentives to invest in renewable energy in the energy transition period $[38,39]$.

It is worth emphasising that increases in electricity prices in Poland particularly hit entrepreneurs. As for individual electricity consumers, these prices are regulated by the state for political reasons. This is done by the Energy Regulatory Office, whose task is to ensure that electricity prices for end users are 'reasonable and rational'. Tariffs for entrepreneurs are no longer subject to such protection-electricity prices for companies are regulated only by the market. Thus, depending on the company size, business customers use tariffs A, B or C. Tariff A is intended for the largest individual end users of electricity, tariff $\mathrm{B}$ - for medium and large companies (connected to the medium voltage grid), and tariff C-for small enterprises and farms (connected to the low voltage grid) [40].

How was the price level from the second half of 2020 assessed by entrepreneurs? Over two-thirds of the respondents assessed it as high (69\%) and only one in five $(22 \%)$ believed that electricity prices in Poland were at the appropriate level. The representatives of the agricultural sector assessed the electricity prices most critically (95\%), followed by the representatives of industry, mining and communal services (80\%), as well as trade (71\%), and accommodation and catering (100\%) (Table 2).

Moreover, the vast majority of entrepreneurs expected further increases in electricity prices in the coming years. Their predictions were more pessimistic than those of the authors of the IRE report. Nearly half of the respondents expected increases in energy prices ranging from $16 \%$ to $50 \%$, and almost $10 \%$ were afraid of increases in energy prices ranging from $50 \%$ to $100 \%$ in the next five years. The company size did not differentiate the opinions in any particular way. Price increases ranging from 15\% to 30\% were most often indicated-this view was most often expressed in companies employing 50 to 149 people (43\%) and in companies with 150 to 249 employees (44\%) (Table 3). 
Table 2. Electricity prices assessed by entrepreneurs-by company size and industry (answers in percentage points). Are the current electricity prices in Poland in relation to the total costs of running a business?

\begin{tabular}{|c|c|c|c|c|c|c|c|c|c|c|c|c|c|}
\hline & 㫯 & 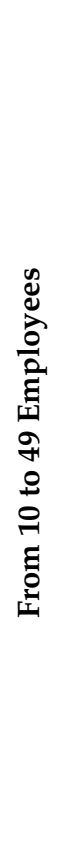 & 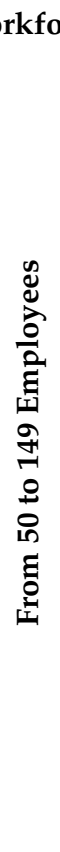 & 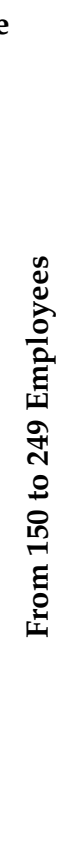 & 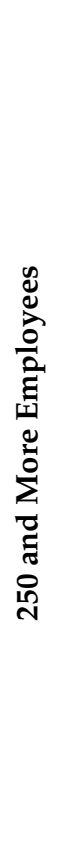 & 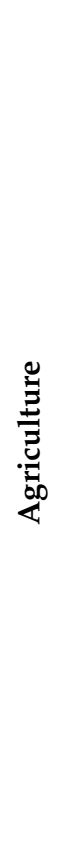 & 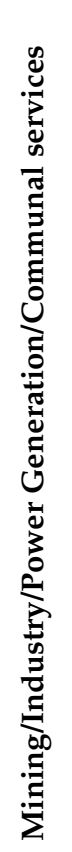 & 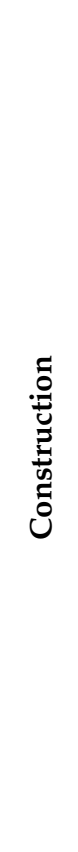 & 莺 & 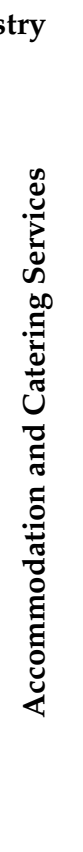 & 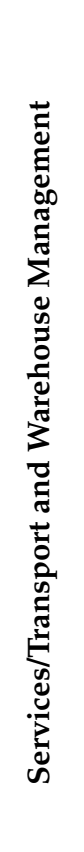 & 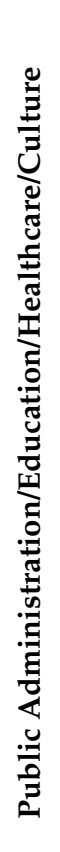 & $\frac{\grave{d}}{\stackrel{\Xi}{0}}$ \\
\hline high & 69 & 67 & 75 & 81 & 53 & $95+$ & $80+$ & $57-$ & 71 & $100+$ & $51-$ & 50 & $29-$ \\
\hline at the right level & 22 & 23 & 23 & $10-$ & 22 & $5-$ & $14-$ & 27 & 27 & - & 31 & 21 & 57 \\
\hline low & 2 & 2 & - & - & 13 & - & 3 & 5 & 2 & - & 1 & - & - \\
\hline I don't know $\backslash$ hard to say & 7 & 8 & $2-$ & 9 & 12 & - & $3-$ & 10 & - & - & $17+$ & 29 & 14 \\
\hline
\end{tabular}

Table 3. Amount of increases in electricity prices expected by entrepreneurs-by workforce (answers in percentage points). By what percentage will energy prices increase in Poland over the next five years?

\begin{tabular}{|c|c|c|c|c|c|}
\hline & \multicolumn{5}{|c|}{ Workforce } \\
\hline & Total & $\begin{array}{c}\text { From } 10 \text { to } \\
49 \text { Employees }\end{array}$ & $\begin{array}{c}\text { From } 50 \text { to } \\
149 \text { Employees }\end{array}$ & $\begin{array}{c}\text { From } 150 \text { to } \\
249 \text { Employees }\end{array}$ & $\begin{array}{c}250 \text { and More } \\
\text { Employees }\end{array}$ \\
\hline By up to $10 \%$ & 15 & 17 & 13 & 9 & 10 \\
\hline Ву 10-15\% & 19 & 18 & 16 & 20 & 30 \\
\hline By $16-30 \%$ & 35 & 32 & 43 & 44 & 38 \\
\hline Вy $31-50 \%$ & 14 & 14 & 14 & 15 & 16 \\
\hline Вy $51-99 \%$ & 4 & 3 & 5 & 4 & - \\
\hline By $100 \%$ or more & 5 & $7+$ & 3 & - & - \\
\hline $\begin{array}{c}\text { I don't know } \backslash \text { hard } \\
\text { to say }\end{array}$ & 8 & 9 & 6 & 7 & 7 \\
\hline
\end{tabular}

Do these concerns affect the actions of entrepreneurs?

\subsection{Actions Taken to Save Energy Costs in Companies}

Three pathways of technological breakthrough-orientation, energy saving and emission reduction-orientation and balanced growth-orientation are provided for different types of OECD countries. However, the largest possibilities for saving energy and introducing innovative solutions are in emerging countries (including Eastern European countries), which have relatively low green productivities and distinct potentials in all the directions for energy saving [41].

The data from 2012 showed that many people did not know whether their company had implemented special energy-saving procedures at all [42]. At that time, only $7 \%$ of the surveyed employees were convinced of the existence of an electricity saving policy (instruction) in their company. Moreover, 14\% of employees believed that this type of 
policy had been implemented, but they were not sure. At the same time, the majority of respondents $(76 \%)$ then declared that they tried to sensibly use electricity on a daily basis, even though their company did not currently have an efficiency policy [42].

What has changed over the decade? Before answering this question, it is worth emphasising that the business environment is not homogeneous. Many evaluations and research reports indicate that company size plays an important role. The report 'Green energy in small and medium-sized enterprises' shows that micro-enterprises (employing 1-9 people) have the lowest awareness of the impact of their activity on the environment in Poland and least frequently undertake activities in this area [43]. The main motivation to take eco-measures is compliance with regulations and laws. The main obstacle to investing in ecology in these smallest companies is the greater workload related to caring for the environment. Small companies (10-49 employees) have greater than average awareness of the impact of their activity on environmental protection and more often take action in this area. The main motivation for their eco-activities is the use of pro-environmental features in building the company's image. Medium-sized companies (50-249 employees) are the most aware of the impact of their activity on environmental protection and most often carry out pro-ecological activities. Among the obstacles to investing in sustainable production, they most often indicate the higher costs of ecologically friendly materials. Medium-sized companies are also definitely more likely to invest in renewable energy and electro-mobility.

These trends have been confirmed in this research: the larger the company, the more often various forms of energy saving are used (Table 4). This dependence results from two reasons. Firstly, the larger the company, the higher the energy consumption and therefore the higher the costs and greater economic incentive to look for savings. Secondly, the initial investment in saving electricity yields relatively high returns on investment. In the case of larger companies, saving is primarily determined by economic reasons. These findings from Poland confirm trends in other countries $[44,45]$. The most common forms of energy saving in companies in Poland are the use of energy-saving light bulbs (93\%), the obligation to turn off the light when leaving the room $(82 \%)$, the use of devices with low electricity consumption $(65 \%)$ and the installation of motion sensors that control lighting in common areas $(51 \%)$ (Table 4$)$.

On the other hand, the longer a company operates on the market, the greater the propensity to take energy-saving measures (Table 4). This issue is directly related to the greater experience of companies operating for longer rather than shorter periods. This in turn translates into the organisational differentiation of these companies, which is of great importance in pro-environmental investments [46]. In this context, the literature emphasises that internal organisational issues in a company, as well as the special role and attitude of senior managers [47] are more important than external factors [48]. However, later studies show that the role of senior managers may be overestimated, with ordinary employees playing a greater role:

... normative pressure affects firms' energy-saving behavior through people who participate in trade associations, who care about firms' image from media reports and who have higher energy-saving consciousness. These people can be ordinary workers or experts in a specific area [49].

Although the type of industry in which a given company operates has an impact on the interest in energy-saving measures, the obtained results indicate that in the case of energy saving and attitudes towards investing in renewable energy, the type of ownership and the related way of managing the company are of considerable importance. 
Table 4. Methods of saving electricity applied in the workplace (answers in percentage points). Are the following methods of saving electricity used in your workplace/company?

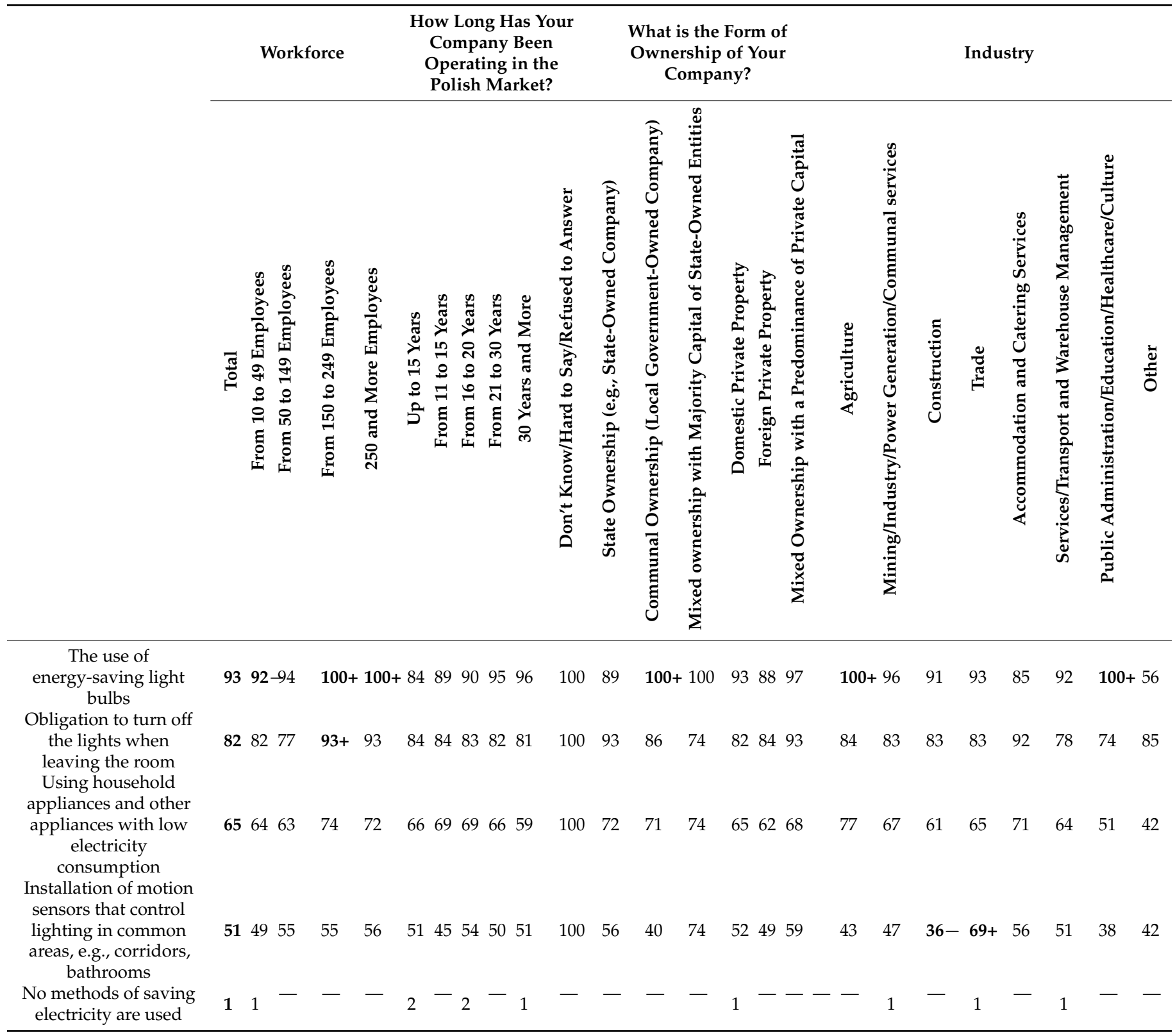

5.3. Readiness to Invest in Renewable Energy According to the Ownership Structure of Enterprises

Although there are analyses in the literature of the factors determining the decisions by companies to invest in research and development (R\&D) [50,51] (it has been shown, for example, that different types of ownership structure and different mechanisms of control over decisions in a company affect its innovativeness) [52], there is no research indicating the relationship between ownership structure and readiness to invest in renewable energy. Moreover, R\&D expenditure should not be equated simply with the innovativeness of companies. Mariana Mazzucato has debunked this myth, pointing out that R\&D activity does not always have a positive impact on growth. Moreover, it is often a negative impactif companies do not have the necessary complementary resources, $R \& D$ becomes just a cost for them [53]. For this reason, the private sector is not that much interested in investing its resources in $R \& D$ and one of the reasons is its increasing short-termism. On the one hand, this is caused by the logic of corporate governance structures that prioritise quarterly returns [54]. On the other hand, it results from macroeconomic conditions, such as low 
interest rates, that make share buybacks more profitable [55]. Investing in new and durable solutions ceases to pay off under the rules of casino capitalism, in which what counts is quick profit rather than a long wait for slow returns.

Investment challenges related to climate change and renewable energy require 'transformative' innovation [56]. It is therefore crucial to establish not only the source of financing such a transformation, but also the characteristics of an energy-friendly atmosphere in various types of enterprises. While at the level of green energy production and financing new energy technologies, differences in the operation of the private and public sectors have been analysed [57], there is still little data on business prosumers from both sectors.

There are no such analyses, particularly with regard to the countries of Eastern Europe. Moreover, it can be assumed that the organisational culture, the capital held and differences in the lengths of possible investment prospects differ fundamentally in individual sectors of the economy and in various types of companies. In transition economies in emerging countries, an interesting challenge is, for example, to identify the differences in attitudes towards relying on renewable energy between domestic and foreign companies [58]. On the one hand, foreign companies can guarantee faster transmission of new technologies. On the other hand, by focusing on quick profit maximisation and the transfer of earned funds to the core countries, long-term investments in renewable energy may be unprofitable for them.

The obtained research results confirm Mazzucato's [53] considerations. Firstly, contrary to the stereotypical opinion that small companies are the most innovative and open to change, the reality in Poland is that they are the least interested in saving energy by investing in renewable energy. The relationship is almost linear: the larger the company, the more often it plans to invest in renewable energy. However, among all companies, $44 \%$ of entrepreneurs thought about investing in renewable energy, among companies with more than 250 employees this percentage was $70 \%$ and was statistically significant (Table 5). Large companies can afford to plan for the long term and count on savings resulting from energy costs over a long period of time. The same relationship between company size and investment readiness holds true for water saving investment plans. Water and energy saving are closely related-there is synergy between these two sectors in the sustainable development policy at both national and company levels [59]. 
Table 5. Percentage of entrepreneurs investing or planning to invest in renewable energy—by workforce, period of operation and industry. Does the company undertake or plan any activities aimed at investing in renewable energy?

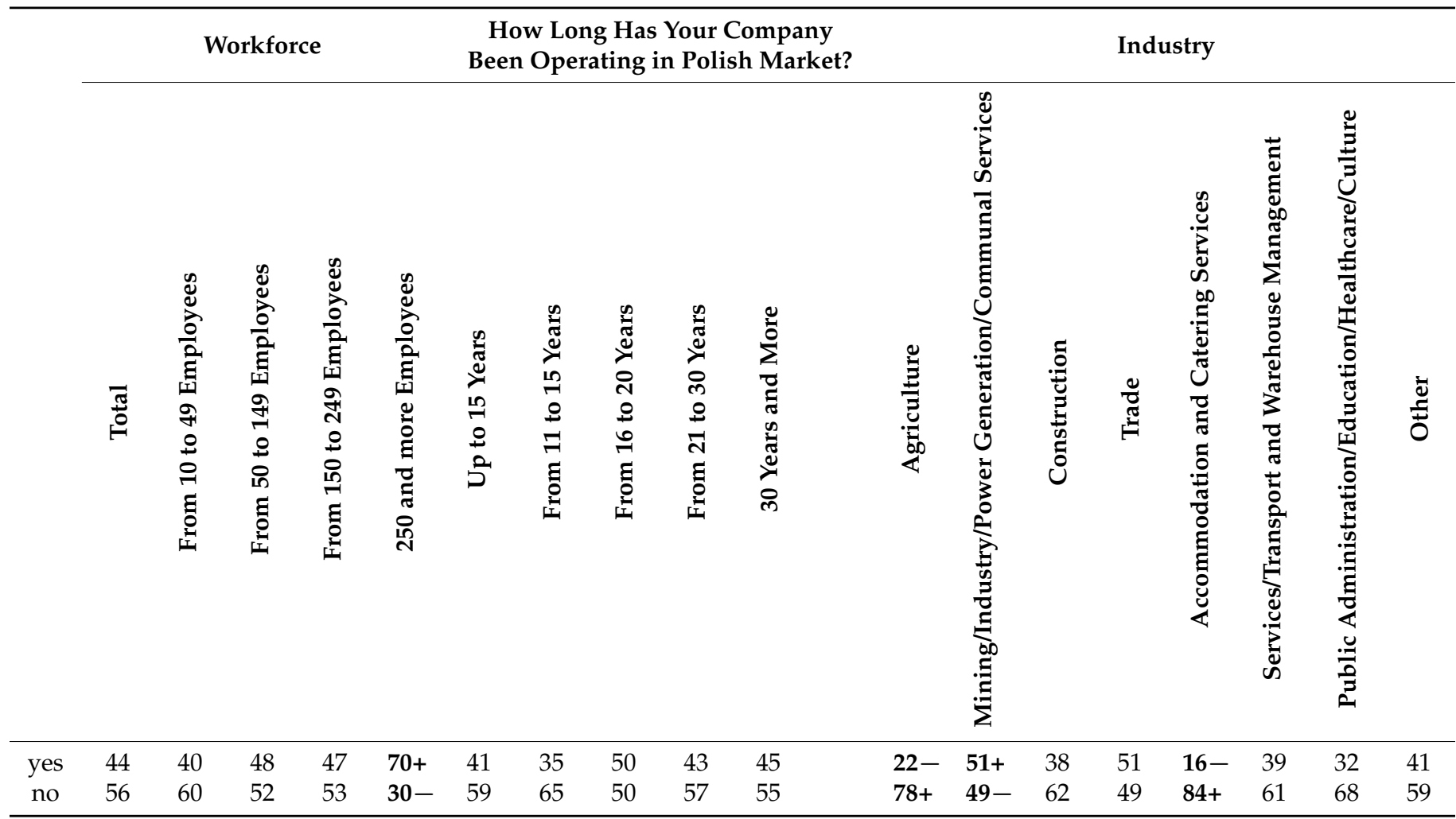

Secondly, the ownership structure of a company plays an important role in looking for savings by investing in renewable energy. The obtained data indicate a significant difference between the public and private sectors. Companies in which the state or local government authorities have a share (such as state-owned companies, municipal companies or mixed companies with majority capital of state-owned entities), plan environmental investments much more often than private companies (Table 6). Among the latter, the representatives of private foreign companies were the least interested in renewable energy-only $27 \%$ expressed such an interest and as many as $73 \%$ did not plan any ecological investments. This may prove that, in their economic strategies, foreign concerns in Poland are constantly guided by access to cheap labour and a large number of educated specialists, who cost less than in the core countries. This also shows that foreign investments are short-term investments-in the event of changes in the global economic situation, they are able to quickly change their place of investment to a more suitable one (with greater resources of cheap labour and less restrictive environmental protection regulations). On the other hand, state-owned or municipal companies have a guaranteed inflow of capital from public budgets and can afford long-term investments. Public entities are also safer for investment loans from banks.

The energy consumption of companies and the growing production costs related to the increases in energy prices have the greatest impact on investments that save energy expenditure in the industrial, mining and municipal services sectors (Table 6). In Poland, these industries are mostly in the public sector. 
Table 6. Percentage of entrepreneurs investing or planning to invest in renewable energy or in water saving-by workforce, period of operation, form of ownership and industry. Does your company take or plan any measures to invest in renewable energy or to save water?

\begin{tabular}{|c|c|c|c|c|c|c|c|c|c|c|c|c|c|c|c|c|c|c|c|c|c|c|c|c|}
\hline & & Wo & rkfor & & & & $\begin{array}{l}\text { ow } \\
\text { our } C \\
\text { en } \mathrm{e} \\
\text { n the } \\
\text { Ma }\end{array}$ & $\begin{array}{l}\text { Lon } \\
\text { Com } \\
\text { Dpe } \\
\text { e Po } \\
\text { arke }\end{array}$ & $\begin{array}{l}\text { g Ha } \\
\text { ipan } \\
\text { ratir } \\
\text { lish } \\
\text { t? }\end{array}$ & & Ow & $\begin{array}{l}\text { Wha } \\
\text { eersh }\end{array}$ & $\begin{array}{l}t \text { Is } t l \\
p \text { of }\end{array}$ & $\begin{array}{l}\text { e For } \\
\text { our }\end{array}$ & $\begin{array}{l}n \text { of } \\
\text { ompa }\end{array}$ & ny? & & & & Indu & stry & & & \\
\hline & సٓ & 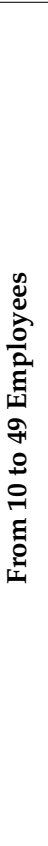 & 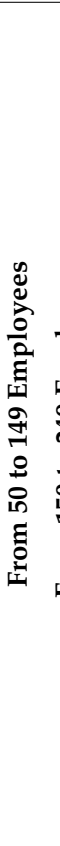 & 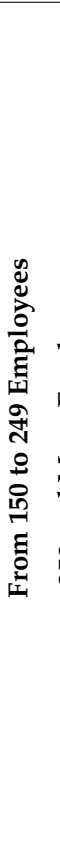 & 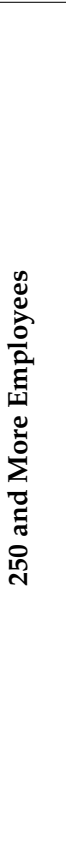 & 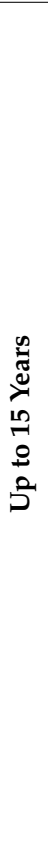 & 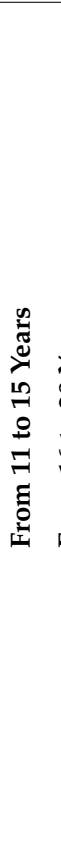 & 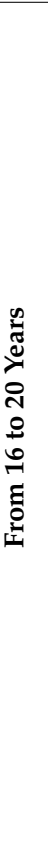 & 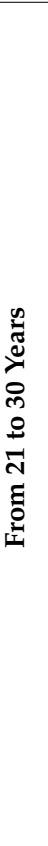 & 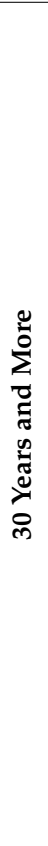 & 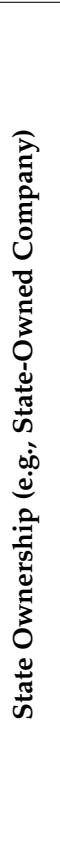 & 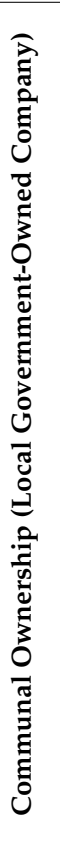 & 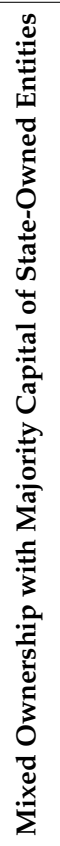 & 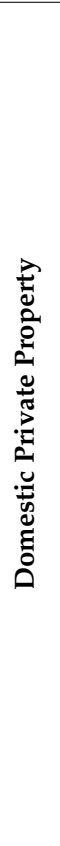 & 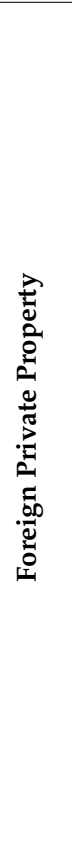 & 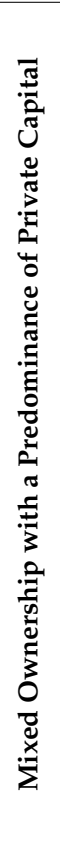 & 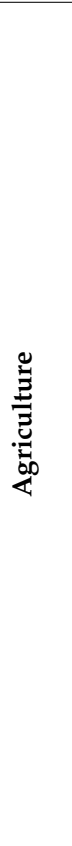 & 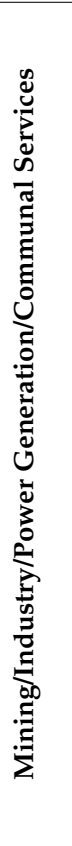 & 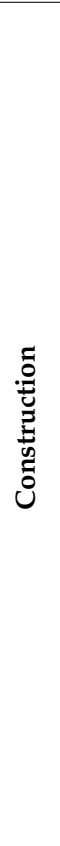 & 窇 & 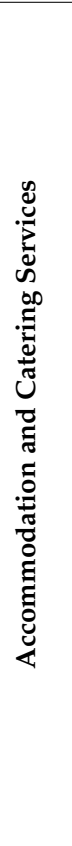 & 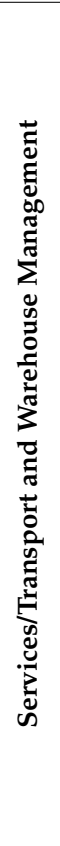 & 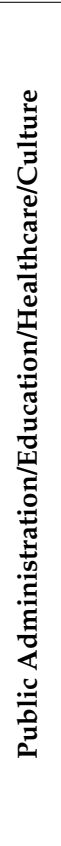 & 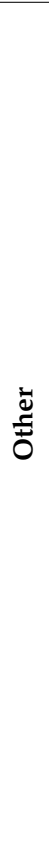 \\
\hline Yes & 54 & 51 & 54 & 65 & $82+$ & 48 & 41 & 60 & 53 & 57 & 70 & $77+$ & 74 & 54 & $27-$ & 54 & 48 & $62+$ & 51 & 54 & 45 & 48 & 42 & 41 \\
\hline $\begin{array}{l}\text { into renewable } \\
\text { energy }\end{array}$ & 44 & 40 & 48 & 47 & $70+$ & 41 & 35 & 50 & 43 & 45 & 70 & $77+$ & 74 & 42 & $20-$ & 40 & $22-$ & $51+$ & 38 & 51 & $16-$ & 39 & 32 & 41 \\
\hline in saving water & 24 & 23 & 17 & 36 & $53+$ & 31 & 21 & 28 & 23 & 22 & 17 & 36 & 74 & 24 & 12 & 32 & 43 & 30 & 28 & $14-$ & 39 & 16 & 17 & 27 \\
\hline No & 46 & 49 & 46 & 35 & $19-$ & 52 & 59 & 40 & 47 & 43 & 30 & $23-$ & 26 & 47 & $73+$ & 46 & 52 & $38-$ & 49 & 46 & 55 & 52 & 58 & 59 \\
\hline
\end{tabular}

5.4. The Attitudes of Entrepreneurs in Poland towards the Concept of the European Green Deal (EGD)

The success in achieving the goals of the EGD including the transition of the European Union towards the climate-neutral economy by reducing carbon emissions towards 55\% by 2030 and achieving carbon neutrality by 2050 requires not only state policies and government commitment. Nor is it only a financial, legal or technological challenge [60]. This transformation will not be successful without convincing society, citizens and entrepreneurs of its purposefulness. It is imperative to understand that public authorities have a large role to play in this process, and that green transitions must be linked to democratic processes and be legitimised by various actors of civil society [61].

The research results show the need to conduct a massive social and information campaign about the advisability of implementing the EGD. Every fifth entrepreneur did not have an opinion on whether the EGD would guarantee the competitiveness of the European economy, and among all the respondents, only 36\% of entrepreneurs in Poland shared the view about the relationship between the zero-emission economy and its competitiveness (Table 7). The only industry in which more people were convinced that the emission-free economy would make it competitive were representatives of the public sector in the areas of education, culture, health service and public administration institutions. This confirms that the public sector has the greatest potential when it comes to investing in renewable energy. With regard to the EGD, the company size did not differentiate the opinions of entrepreneurs. 
Table 7. EU climate policy assessed by entrepreneurs in Poland-by workforce and industry (answers in percentage points). Will the EU plans to reduce $\mathrm{CO}_{2}$ to zero and make the European economy emission-free (i.e., the European Green Deal) ensure the competitiveness of the European economy?

\begin{tabular}{|c|c|c|c|c|c|c|c|c|c|c|c|c|c|}
\hline & \multicolumn{5}{|c|}{ Workforce } & \multicolumn{8}{|c|}{ Industry } \\
\hline & 吾 & 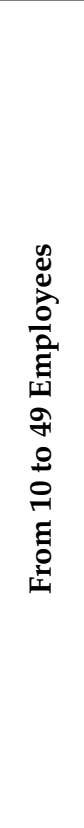 & 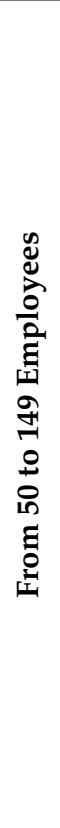 & 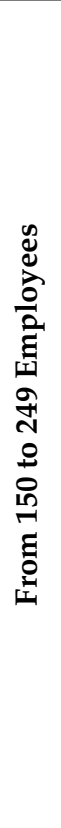 & 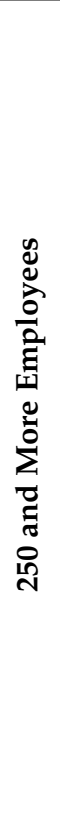 & 苞 & 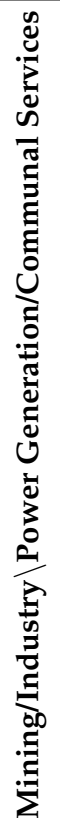 & 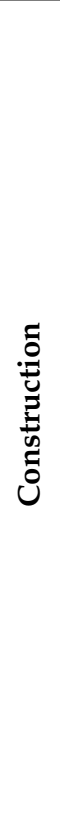 & 莺 & 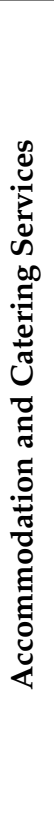 & 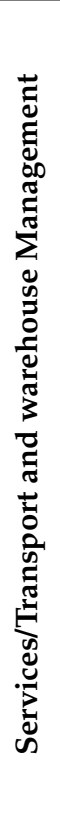 & 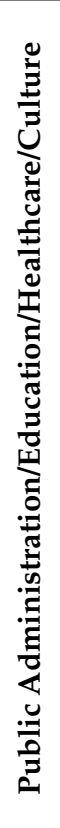 & $\frac{\stackrel{ \pm}{ే}}{0}$ \\
\hline Definitely yes & 12 & 13 & 10 & 15 & 8 & 10 & 13 & 15 & 11 & 9 & 10 & 26 & 28 \\
\hline Somewhat yes Probably yes & 24 & 23 & 28 & 14 & 22 & 24 & 24 & 24 & 20 & 32 & 27 & 17 & 15 \\
\hline Neither yes nor no & 21 & 21 & 21 & 17 & 23 & 20 & 20 & 27 & 20 & - & 21 & 27 & 29 \\
\hline Somewhat not & 24 & $21-$ & 28 & 33 & 39 & 26 & 30 & 16 & 24 & 30 & 19 & 19 & 14 \\
\hline Definitely not & 18 & 20 & 12 & 20 & 8 & 17 & 13 & 18 & 21 & 28 & 21 & 11 & 15 \\
\hline Yes & 36 & 37 & 38 & 28 & 30 & 34 & 37 & 39 & 31 & 41 & 36 & 43 & 42 \\
\hline No & 42 & 41 & 40 & 53 & 47 & 43 & 43 & 34 & 45 & 59 & 40 & 30 & 29 \\
\hline I don't know / hard to say & 2 & 2 & 1 & 2 & - & 3 & 1 & - & 4 & - & 3 & - & - \\
\hline
\end{tabular}

\section{Conclusions}

Without the involvement of entrepreneurs in achieving the goals of EGD, this project will have no chance of success. Previous analyses of the behaviour of entrepreneurs who try to act in accordance with the principles of sustainable development and, at that same time, strive to generate profit have indicated that there may be tensions between the ecological and economic dimensions [62].

However, in countries such as Poland, where the energy system is dependent on coal, which results in constant increases in energy prices, ecological solutions aimed at saving energy and investing in independent and renewable energy sources may be among the important strategies of entrepreneurs' activities. However, the attitudes of entrepreneurs may be differentiated by various reasons: their level of knowledge, environmental awareness and other individual features. Variables from the macrosocial level are equally important.

In addition, external aspects functioning at the macro-social level, such as access to information on new energy-saving technologies for business available on the market or access to loans and co-financing investments related to renewable energy may affect the activation of renewable energy adoption in industry in Poland. This, however, requires verification in further research.

The presented research results shed light on a new area that may be helpful in explaining attitudes towards investments in renewable energy. Previous analyses of the relationship between the form of ownership and energy policy concerned the form of energy production and management at the state policy level [63]. This article indicates that differences in the form of ownership can also be a factor in the analysis of finan- 
cial and energy strategies implemented by entrepreneurs and their readiness to become business prosumers.

Studies on the internal diversification of the entrepreneurial environment in terms of the company size, industry and ownership structure as factors supporting or delaying energy transition are particularly important in countries where the energy sector is dependent on fossil sources. Those responsible for development policy in different companies may have a different investment perspective, measure the company's operating costs differently, and approach environmental challenges differently. However, their choices and the energy policy implemented at company level will translate into an energy model dominating the business sector on a macro-social scale.

Differences in the approach to energy saving and reducing costs in a company by taking on the role of a business prosumer show that the increase in energy prices as a factor motivating entrepreneurs to invest in renewable energy does not always work. Furthermore, even the potential risk of further increases in electricity prices does not have to translate into supporting the business prosumer model as long as a company is focused on quick profits, not slow returns on investment. This is in line with previous research results showing that an increase in energy prices does not automatically affect renewable energy technological innovation in the short run-this kind of impact may appear in the long run [64].

However, these quantitative results show some consistent trends. Firstly, large companies with over 250 employees are more ready to invest in renewable energy. It is too much of a financial burden for small companies. Secondly, state-owned, communal and mixed ownership companies with dominant state capital are more interested in investing in renewable energy for their own needs than private sector companies. Representatives of communal companies and companies with dominant state capital also more often declared taking actions to save energy. The length of time a company has operated in the market is of no great importance for the company's approach to energy policy. A limitation of this research is that it does not take account of the location of the surveyed companies. In the context of business prosumers, this variable (companies located in cities, villages and on the outskirts of cities) may be important in the case of both micro wind turbines and photovoltaics. The regional division of individual societies is also associated with differences in economic potential and a diversified (for cultural reasons) attitude towards renewable energy. It is worth considering this aspect in future research.

The issue of how entrepreneurs and other actors of public life assess the EGD requires further research. It is also necessary to constantly monitor the implementation of the EGD goals in countries such as Poland, where energy transition may be a source of controversy and social and political tensions.

The questions posed in this article are also valid in other countries. Just as the challenges of the Global Green New Deal are not feasible without adopting the perspective of the Global South countries [65], the EGD may encounter the greatest problems in Easter Europe. For this reason, it is particularly important to check whether entrepreneurs in other former Eastern bloc countries are ready for transformations related to just transition goals. Creation of 'green jobs' and investments in renewable energy to protect the climate are not the only challenges related to this problem [66]. In the former countries of the Eastern bloc, there are additional typical systemic barriers resulting from centralist and authoritarian political tendencies, as is the case in Poland and Hungary, where the governments defend the state's full control over key entities in the energy sector and its infrastructure [67], as well as the bureaucratisation and formalisation of climate policy. The way in which energy transition unfolds in Eastern Europe will affect the region's future place in the geopolitical order. These are, however, considerations on a completely different topic.

Author Contributions: Conceptualization, P.Ż. (Piotr Żuk); Investigation, P.Ż. (Piotr Żuk) and P.Ż. (Paweł Żuk); Methodology, P.Ż. (Piotr Żuk); Writing—original draft, P.Ż. (Piotr Żuk) and P.Ż. (Paweł Żuk). All authors have read and agreed to the published version of the manuscript. 
Funding: This research was funded by The National Science Centre, grant number 2019/33/B/HS6/00139.

Institutional Review Board Statement: Not applicable.

Informed Consent Statement: Not applicable.

Data Availability Statement: Not applicable.

Acknowledgments: This research project was supported by The National Science Centre, Poland (NCN), under Grant No.: 2019/33/B/HS6/00139.

Conflicts of Interest: The authors declare no conflict of interest.

\author{
Abbreviations \\ CATI Computer-Assisted Telephone Interviewing \\ EGD European Green Deal \\ ETS Emissions Trading System \\ IRE Institute for Renewable Energy \\ R\&D Research and Development
}

\title{
References
}

1. Kasprzak, M. Poland's Wholesale Electricity Prices Rise to the Highest in Europe. Available online: https://ember-climate.org/ commentary/2020/10/23/polands-electricity-prices-rise-to-the-highest-in-europe/ (accessed on 9 March 2021).

2. Instytut Energetyki Odnawialnej. Rynek Fotowoltaiki w Polsce; Instytut Energetyki Odnawialnej: Warszawa, Poland, 2020.

3. Sieńko, A. Polskie Firmy Czeka Potężna Zrzutka na prąd. Na Stare Elektrownie Pójdą Miliony. Available online: https: / / spidersweb.pl/bizblog/oplata-mocowa-2021-polskie-firmy/ (accessed on 9 March 2021).

4. Instytut Energii Odnawialnej. Rynek Fotowoltaiki w Polsce, 9th ed.; Instytut Energii Odnawialnej: Warszawa, Poland, $2021 ;$ p. 25.

5. Żuk, P. Employment structures, employee attitudes and workplace resistance in neoliberal Poland. Econ. Labour Relat. Rev. 2017, 28, 91-112. [CrossRef]

6. Mikołajuk, H.; Zatorska, M.; Stępniak, E.; Wrońska, I. Informacja statystyczna o energii elektrycznej. Biul. Miesięczny Agencji Rynk. Energii 2020, 12, 324.

7. Antosiewicz, M.; Nikas, A.; Szpor, A.; Witajewski-Baltvilks, J.; Doukas, H. Pathways for the transition of the Polish power sector and associated risks. Environ. Innov. Soc. Transit. 2020, 35, 271-291. [CrossRef]

8. Żuk, P.; Żuk, P.; Pluciński, P. Coal basin in Upper Silesia and energy transition in Poland in the context of pandemic: The socio-political diversity of preferences in energy and environmental policy. Resour. Policy 2021, 71, 101987. [CrossRef]

9. Kuchler, M.; Bridge, G. Down the black hole: Sustaining national socio-technical imaginaries of coal in Poland. Energy Res. Soc. Sci. 2018, 41, 136-147. [CrossRef]

10. Bendyk, E.; Papajak, U.; Popkiewicz, M.; Sutowski, M. Polski Węgiel; Wydawnictwo Krytyki Politycznej: Warszawa, Poland, 2015.

11. Żuk, P. The Decarbonization of Society as a System Change. Soc. Nat. Resour. 2017, 30, 261-263. [CrossRef]

12. Żuk, P.; Żuk, P. Between Private Property, Authoritarian State and Democracy: Clearing Trees in Cities and Destroying the Białowieża Forest in Poland. Capital. Nat. Soc. 2020, 32, 56-76. [CrossRef]

13. Żuk, P.; Szulecki, K. Unpacking the right-populist threat to climate action: Poland's pro-governmental media on energy transition and climate change. Energy Res. Soc. Sci. 2020, 66. [CrossRef]

14. Szulecki, K. Securitization and state encroachment on the energy sector: Politics of exception in Poland's energy governance. Energy Policy 2020, 136, 111066. [CrossRef]

15. Żuk, P.; Toporowski, J. Capitalism after communism: The triumph of neoliberalism, nationalist reaction and waiting for the leftist wave. Econ. Labour Relat. Rev. 2020, 31, 158-171. [CrossRef]

16. Zapletalová, V.; Komínková, M. Who is fighting against the EU's energy and climate policy in the European Parliament? The contribution of the Visegrad Group. Energy Policy 2020, 139. [CrossRef]

17. Pollin, R.; Callaci, B. The Economics of Just Transition: A Framework for Supporting Fossil Fuel-Dependent Workers and Communities in the United States. Labor Stud. J. 2019, 44, 93-138. [CrossRef]

18. Brauers, H.; Oei, P.-Y. The political economy of coal in Poland: Drivers and barriers for a shift away from fossil fuels. Energy Policy 2020, 144, 111621:1-111621:12. [CrossRef]

19. Peña, J.I.; Rodríguez, R. Are EU's Climate and Energy Package 20-20-20 targets achievable and compatible? Evidence from the impact of renewables on electricity prices. Energy 2019, 183, 477-486. [CrossRef]

20. Ministerstwo Klimatu i Środowiska. Polityka Energetyczna Polski do 2040 r. Załącznik do Uchwały nr 22/2021 Rady Ministrów z Dnia 2 Lutego 2021 r. Available online: https:/ /www.gov.pl/attachment/3209a8bb-d621-4d41-9140-53c4692e9ed8 (accessed on 24 April 2021).

21. Kuriqi, A.; Pinheiro, A.N.; Sordo-Ward, A.; Bejarano, M.D.; Garrote, L. Ecological impacts of run-of-river hydropower plantsCurrent status and future prospects on the brink of energy transition. Renew. Sustain. Energy Rev. 2021, 142. [CrossRef] 
22. Gnatowska, R.; Moryń-Kucharczyk, E. Current status of wind energy policy in Poland. Renew. Energy 2019, 135, 232-237. [CrossRef]

23. Lombardi, L.; Mendecka, B.; Carnevale, E.; Stanek, W. Environmental impacts of electricity production of micro wind turbines with vertical axis. Renew. Energy 2018, 128, 553-564. [CrossRef]

24. Żuk, P.; Żuk, P. Offshoring, labour migration and neo-liberalisation: Nationalist responses and alternatives in Eastern Europe Econ. Labour Relat. Rev. 2018, 29, 97-117. [CrossRef]

25. Romer, P.M. Increasing returns and long-run growth. J. Political Econ. 1986, 94, 1002-1037. [CrossRef]

26. Wallerstein, I. World-Systems Analysis: An Introduction; Duke University Press: Durham, NC, USA, 2004.

27. Kong, D.; Yang, X.; Xu, J. Energy price and cost induced innovation: Evidence from China. Energy 2020, 192, 116586. [CrossRef]

28. Sadath, A.C.; Acharya, R.H. Effects of energy price rise on investment: Firm level evidence from Indian manufacturing sector. Energy Econ. 2015, 49, 516-522. [CrossRef]

29. Mallick, H.; Mahalik, M.K.; Sahoo, M. Is crude oil price detrimental to domestic private investment for an emerging economy? The role of public sector investment and financial sector development in an era of globalization. Energy Econ. 2018, 69, 307-324 [CrossRef]

30. Song, Y.; Ji, Q.; Du, Y.-J.; Geng, J.-B. The dynamic dependence of fossil energy, investor sentiment and renewable energy stock markets. Energy Econ. 2019, 84, 104564. [CrossRef]

31. Ai, H.; Xiong, S.; Li, K.; Jia, P. Electricity price and industrial green productivity: Does the 'low-electricity price trap' exist? Energy 2020, 207, 118239. [CrossRef]

32. Timmermans, J.; van der Heiden, S.; Born, M.P. Policy entrepreneurs in sustainability transitions: Their personality and leadership profiles assessed. Environ. Innov. Soc. Transit. 2014, 13, 96-108. [CrossRef]

33. Hassen, S.; Gebrehiwot, T.; Arega, T. Determinants of enterprises use of energy efficient technologies: Evidence from urban Ethiopia. Energy Policy 2018, 119, 388-395. [CrossRef]

34. Żuk, P.; Żuk, P. On the Socio-Cultural Determinants of Polish Entrepreneurs' Attitudes towards the Development of Renewable Energy: Business, Climate Skepticism Ideology and Climate Change. Energies 2021, 14, 3418. [CrossRef]

35. Żuk, P.; Żuk, P. Environmental awareness and higher education: Differences in knowledge and the approach to ecology between students of technical sciences and the humanities in Poland. Appl. Environ. Educ. Commun. 2018, 17, 150-160. [CrossRef]

36. Żuk, P.; Pacześniak, A. Sustainable Development, Energy Transition, and Climate Challenges in the Context of Gender: The Framework of Gender Determinants of Environmental Orientation in Poland. Sustainability 2020, 12, 9214. [CrossRef]

37. Instytut Energetyki Odnawialnej. Prognoza Kosztów Wytwarzania i Cen Energii Elektrycznej do 2040 Roku—Aktualizacja Marzec 2020; Instytut Energetyki Odnawialnej: Warszawa, Poland, 2020.

38. Gabriel, C.-A. What is challenging renewable energy entrepreneurs in developing countries? Renew. Sustain. Energy Rev. 2016, 64, 362-371. [CrossRef]

39. Parthan, B.; Osterkorn, M.; Kennedy, M.; Hoskyns, S.J.; Bazilian, M.; Monga, P. Lessons for low-carbon energy transition: Experience from the Renewable Energy and Energy Efficiency Partnership (REEEP). Energy Sustain. Dev. 2010, 14, 83-93. [CrossRef]

40. Fodrowska, K. Ceny Prądu 2021—Czekają Nas Wyższe Rachunki za Energię Elektryczną. Available online: https://enerad.pl/ aktualnosci/ceny-pradu-2021/ (accessed on 9 March 2021).

41. Wang, Y.; Sun, X.; Wang, B.; Liu, X. Energy saving, GHG abatement and industrial growth in OECD countries: A green productivity approach. Energy 2020, 194, 116833. [CrossRef]

42. RWE Polska. Jak Oszczędzamy Energię w Miejscu Pracy? Raport RWE Polska. Available online: https://www.cire.pl/pliki/1/ Raport_RWE_13_12_20-12.pdf (accessed on 9 March 2021).

43. EFL. Zielona Energia w MŚP. Pod Lupą. Raport Specjalny 2020. EFL. Available online: https://efl.pl/wp-content/uploads/2020 /08/Raport_ZielonaEnergiaMSP.pdf (accessed on 9 March 2021).

44. Cagno, E.; Trianni, A.; Abeelen, C.; Worrell, E.; Miggiano, F. Barriers and drivers for energy efficiency: Different perspectives from an exploratory study in the Netherlands. Energy Convers. Manag. 2015, 102, 26-38. [CrossRef]

45. Trianni, A.; Cagno, E.; Farné, S. Barriers, drivers and decision-making process for industrial energy efficiency: A broad study among manufacturing small and mediumsized enterprises. Appl. Energy 2016, 162, 1537-1551. [CrossRef]

46. Thollander, P.; Backlund, S.; Trianni, A.; Cagno, E. Beyond barriers-A case study on driving forces for improved energy efficiency in the foundry industries in Finland, France, Germany, Italy, Poland, Spain, and Sweden. Appl. Energy 2013, 111, 636-643. [CrossRef]

47. Liu, X.; Yamamoto, R.; Suk, S. A survey analysis of energy saving activities of industrial companies in Hyogo, Japan. J. Clean. Prod. 2014, 66, 288-300. [CrossRef]

48. Blass, V.; Corbett, C.J.; Delmas, M.A.; Muthulingam, S. Top management and the adoption of energy efficiency practices: Evidence from small and medium-sizedmanufacturing firms in the US. Energy 2014, 65, 560-571. [CrossRef]

49. Zhang, Y.; Wei, Y.; Zhou, G. Promoting firms' energy-saving behavior: The role of institutional pressures, top management support and financial slack. Energy Policy 2018, 115, 230-238. [CrossRef]

50. Love, J.H.; Ashcroft, B.; Dunlop, S. Corporate structure, ownership and the likelihood of innovation. Appl. Econ. 1996, 28, 737-746. [CrossRef] 
51. Beneito, P. Choosing among alternative technological strategies: An empirical analysis of formal sources of innovation. Res. Policy 2003, 32, 693-713. [CrossRef]

52. Ortega-Argilés, R.; Moreno, R.; Caralt, J.S. Ownership structure and innovation: Is there a real link? Ann. Reg. Sci. 2005, 39, 637-662. [CrossRef]

53. Mazzucato, M. The Entrepreneurial State: Debunking Public vs. Private Sector Myths; Anthem Press: London, UK, 2013.

54. Kay, J. The Kay Review of UK Equity Markets and Long-Term Decision Making. Final Report; July 2012. Available online: https:/ / www.gov.uk/government/uploads/system/uploads/attachment_data/file/253454/bis-12-917-kay-review-ofequity-markets-final-report.pdf (accessed on 9 March 2021).

55. Mazzucato, M.; Semieniuk, G. Public financing of innovation: New questions. Oxf. Rev. Econ. Policy 2017, 33, 24-48. [CrossRef]

56. Mazzucato, M. From Market Fixing to Market Creating: A New Framework for Innovation Policy. Ind. Innov. 2016, 23, 140-156. [CrossRef]

57. Mazzucato, M.; Semieniuk, G. Financing renewable energy: Who is financing what and why it matters. Technol. Forecast. Soc. Chang. 2018, 127, 8-22. [CrossRef]

58. Ankrah, I.; Lin, B. Renewable energy development in Ghana: Beyond potentials and commitment. Energy 2020, 198. [CrossRef]

59. Esmaeil, A.; McLellan, B.; Tezuka, T. The economic synergies of modelling the renewable energy-water nexus towards sustainability. Renew. Energy 2020, 162, 1347-1366. [CrossRef]

60. Sikora, A. European Green Deal-legal and financial challenges of the climate change. ERA Forum 2021, 21, 681-697. [CrossRef]

61. Pianta, M.; Lucchese, M. Rethinking the European Green Deal: An Industrial Policy for a Just Transition in Europe. Rev. Radic. Political Econ. 2020, 52, 633-641. [CrossRef]

62. Cesinger, B.; Vallaster, C.; Müller, J.M. The ebb and flow of identity: How sustainable entrepreneurs deal with their hybridity. Eur. Manag. J. 2021, 1-13, in press. [CrossRef]

63. Haney, A.B.; Pollitt, M.G. New models of public ownership in energy. Int. Rev. Appl. Econ. 2013, 27, 174-192. [CrossRef]

64. Lin, B.; Chen, Y. Does electricity price matter for innovation in renewable energy technologies in China? Energy Econ. 2019, 78, 259-266. [CrossRef]

65. Chen, Y.; Li, A. Global Green New Deal: A Global South perspective. Econ. Labour Relat. Rev. 2021, 32, 170-189. [CrossRef]

66. Stilwell, F. From green jobs to Green New Deal: What are the questions? Econ. Labour Relat. Rev. 2021, 32, 155-169. [CrossRef]

67. Szabo, J.; Fabok, M. Infrastructures and state-building: Comparing the energy politics of the European Commission with the governments of Hungary and Poland. Energy Policy 2020, 138, 111253. [CrossRef] 